\title{
Inquietações, provocações, reflexões, acolhida e encontro promovido pela educação popular e o serviço social: um diálogo com Oscar Jara
}

\section{Concerns, provocations, reflections, reception and meeting promoted by popular education and social work: a dialogue with Oscar Jara}

Fabricio Gobetti Leonardi ${ }^{1}$, Raiane Patrícia Severino Assumpção ${ }^{2}$

Esta entrevista foi tecida e realizada no âmbito do intercâmbio acadêmico realizado por um dos autores, na Costa Rica, tendo como cenários a Universidade de Costa Rica e o Centro de Estudos e Publicações Alforja (CEP Alforja), cujo diretor é o professor Oscar Jara Holliday ${ }^{3}$.

As inquietações e os estímulos para pensar as questões que constituíram a entrevista advieram do trabalho realizado a partir da Universidade Federal de São Paulo (Unifesp), seja no curso de Serviço Social, como nas ações de extensão e pesquisa na linha da educação popular e das metodologias participativas (LEONARDI; ASSUMPÇÃO, 2016, p. 437).

Desde 2010, inquietações e reflexões nos convocam a pensar a educação popular e sua relação com o serviço social, uma vez que aquela tem sido relegada da história da profissão após o movimento de reconceituação que marca a aproximação e, logo em seguida, o afastamento entre serviço social e educação popular.

Essa relação, bastante insipiente em termos de publicações, desde então é marcada, principalmente, pela discussão sobre o trabalho profissional relacionado aos movimentos sociais, organização, mobilização popular e participação popular ${ }^{4}$. Parece ser difícil para o

\footnotetext{
${ }^{1}$ Mestre em Ciências da Saúde pela Universidade Federal de São Paulo, Brasil; assistente social na mesma instituição, onde coordena o Centro de Educação em Direitos Humanos e o Setor de Saúde do Estudante da Pró-Reitoria de Assuntos Estudantis / Master in Health Sciences, Federal University of São Paulo, Brazil; social worker at the same institution, where he coordinates the Human Rights Education Center and the Student Health Sector of the Dean of Student Affairs. E-mail: fabricio.leonardi@unifesp.br.

2 Doutora em Sociologia pela Universidade Estadual Paulista Júlio de Mesquita Filho, São Paulo, Brasil; professora adjunta IV da Universidade Federal de São Paulo, Campus Baixada Santista, Brasil; pró-reitora de Extensão e Cultura na mesma instituição; líder do Grupo de Pesquisa e Extensão em Violência do Estado, Direitos Humanos e Educação Popular; membro do Centro de Educação em Direitos Humanos / $\mathrm{PhD}$ in Sociology from Universidade Estadual Paulista Júlio de Mesquita Filho, São Paulo, Brazil; adjunct professor IV at the Federal University of São Paulo, Campus Baixada Santista, Brazil; dean of Extension and Culture in the same institution; leader of the Research and Extension Group on State Violence, Human Rights and Popular Education; member of the Human Rights Education Center. E-mail: raianeps@uol.com.br.

${ }^{3}$ Oscar Jara Holliday, peruano radicado na Costa Rica, é considerado um dos maiores pensadores e divulgadores vivos da educação popular na América Latina, com atuação a partir do Centro de Estudos e Publicações Alforja (CEP Alforja). Conhecido internacionalmente por seus escritos sobre Sistematização de Experiências e Educação Popular, lança, em 2019, o livro La Educacción Popular Latinoamericana.

${ }^{4}$ Muito embora muitos trabalhos sobre educação popular e saúde, educação popular e comunidades tradicionais, também tenham pautado práticas e concepções de profissionais a partir dos espaços sócio-ocupacionais.
}

Rev. Ed. Popular, Uberlândia, Edição Especial, p. 242-258, jul. 2020. 
serviço social se apropriar ou mesmo dialogar com o marco teórico-metodológico da EP, considerando as diversas tendências - e dentro delas suas diferenças internas - de práticas a concepções, ainda que muitos assistentes sociais sustentem que também são educadores populares e/ou trabalham na linha da EP.

As especificidades e características definidoras de grupos particulares autonomeados de "educação popular", ou mesmo o próprio perfil dos educadores populares dos diversos matizes, não possibilitam encontrar uma "educação popular" ampla, aglutinadora, abrangente e, ao mesmo tempo, congregadora, que possa tomar como responsabilidade o conjunto de questões que se movem sob ordem do que se nomeia "educação popular". Todavia, o serviço social, como uma das profissões da área da saúde, ao não compreender ou dialogar com essa diversidade da EP, tomando-a como pura fragmentação, deixa de perceber que ela está “cimentada" na construção de "um outro mundo", a partir do compromisso ético-político com a transformação da sociedade desde uma posição "crítica, popular, política, social e comunitária" (GADOTTI, 2012, p. 11), que também são compromissos do serviço social brasileiro.

O profundo respeito aos sujeitos sociais e suas trajetórias de vida - concepções de mundo e experiências de violência ou afeto, marcas trazidas da exploração capitalista, condição de necessidades insatisfeitas, não acesso a direitos, sob os quais se ergue o trabalho problematizador que pretende construir, junto com esses sujeitos, as possibilidades de virada de jogo - a práxis revolucionária que é a grande utopia sob a qual se assenta o trabalho dos/as educadores/as populares.

A partir do contato direto com a realidade, das diversas linguagens e das metodologias problematizadoras, participativas e impregnada de sentidos, a EP tem protagonizado, de forma forte e efetiva, o trabalho com a classe trabalhadora e com os setores mais marginalizados e subalternizados da sociedade. Ao utilizar a contradição da vida como mote para a transformação do mundo, a EP pode ser uma grande aliada do serviço social, ajudando a descobrir o sentido pedagógico da prática profissional do assistente social e a complexidade dos processos de consciência e leitura de mundo.

Nesse sentido, esta entrevista é uma tentativa de diálogo construtivo para que se possa contribuir com o futuro debate sobre serviço social e educação popular a partir do encontro solidário entre assistentes sociais e educadores populares. 


\section{Trajetória, vida acadêmica e vinculação com a educação popular}

Oscar Jara - Eu começo a me envolver em processos de educação popular no Peru, meu país de origem, atuando com movimentos juvenis, em ações e reflexões entre jovens no movimento do qual eu fazia parte, vinculado à Igreja, e fazendo um trabalho de apoio organizativo, no momento em que surge a Teologia da Libertação. Então, há um ponto interessante nos anos 70, em que tenho a oportunidade de participar em um movimento católico, a UNEC, onde estava presente Gustavo Gutierrez, no momento em que escrevia o livro Teologia da Libertação que virou tão famoso e foi chave para orientar as comunidades de base da época.

Eu tenho então, desde muito jovem, uma formação cristã vinculada a processos de educação popular e de compromisso com os pobres. Neste mesmo ano, eu tenho a oportunidade de ler $A$ educação como prática da liberdade e a Pedagogia do Oprimido, de Paulo Freire, que estava nesse momento no Chile. Eu tinha 20 anos e lidava com grupos juvenis em um sentido organizativo, político e espiritual. No ano anterior, o ano de 1969, fiz um curso de três meses de alfabetização conscientizadora para aprender o método Paulo Freire. Como atividade desse curso, era necessário desenvolver uma prática, aplicando o método de universo vocabular, temas geradores, investigação temática etc., e eu escolhi fazer no bairro onde participava. Busquei pessoas que queriam se alfabetizar e encontrei cinco senhoras idosas que viviam no Morro São Cristóbal, em Lima. Fiz uma prática muito preliminar, inicial, de aplicar o método de alfabetização e esse foi meu início como educador popular. Foram meus primeiros contatos com os textos de Freire. Depois, ao chegar Allende ao governo no Chile, há uma possibilidade de construção democrática de um projeto socialista, de um projeto revolucionário na América Latina, que nos cria muita esperança.

Neste tempo, as canções chilenas, como as de Victor Jara, dos irmãos Parra, de Quilapayún, faziam sentido para a composição do meu ideário: tocar violão, trabalhar com jovens a partir da Teoria da Libertação, alfabetizar numa perspectiva marcada pelo pensamento de Paulo Freire, e também a leitura do livro As veias abertas da América Latina, de Eduardo Galeano. Aos 20 anos essas três leituras me questionaram e motivaram muito: Teologia da Libertação, Pedagogia do oprimido e As veias abertas. 
Era o momento em que militares progressistas, no Peru, em 1968, fizeram uma mudança social importante: a reforma agrária, nacionalização do petróleo e minas, reforma educacional etc., um momento muito movimentado e motivador para um jovem que queria se comprometer com sua realidade. Assim que, com essas experiências, me enviam para fazer um projeto de trabalho com jovens na serra peruana, em Huancayo, no centro do país, e para alfabetizar camponeses nas comunidades. Eu acho agora que foi uma alfabetização muito precária e só com os elementos que eu tinha, mas foram somente alguns meses.

Depois dessa experiência se cria um importante projeto de alfabetização no norte do país, em uma zona de aplicação da reforma agrária, e me integro a uma entidade em criação o CIPCA (Centro de Investigación y Promoción del Campesinado) e participo em uma equipe de alfabetização com pessoas que conheciam muito melhor o método de Paulo Freire, e que tinham muito conhecimento sobre a parte mais técnica do processo de alfabetização. Lá é onde desenvolvo mais profundamente uma ótica e uma perspectiva de educação popular. $\mathrm{O}$ fato de trabalhar de maneira mais sistemática e coletiva no processo de alfabetização, na lógica freireana, dialógica, construída com a gente do povo etc., em um contexto onde se dava também uma grande luta camponesa e movimentos de tomada de terras. Aí é onde o processo de educação, vinculado aos processos de organização, vai me aparecendo como elemento fundamental. Por exemplo, nesse momento, Freire falava em fazer primeiro a conscientização para, em seguida, as pessoas conscientes poderem fazer uma ação organizada consciente. Mas o que a gente ia vivendo era o contrário: práticas em que a ação organizada era o que levava a tomada de consciência, ou seja, que a conscientização não é algo prévio, mas algo que é parte do processo organizativo. Isso eu vivo e me marca muito fortemente. Dou-me conta de que naquelas zonas, nas quais íamos fazer o nosso trabalho, as pessoas podiam ter uma visão crítica das coisas, mas a situação crítica que viviam as levava a organizarem-se e os níveis de consciência vinham com a organização. Aí aprendo outra coisa que é fundamental: a escutar, escutar as pessoas, perceber como falam, e tentar entender sua maneira de ver o mundo. Por isso é que eu afirmo que, embora nós que íamos alfabetizar os camponeses, na verdade fomos nós os alfabetizados por eles. Isso em um lugar que eu não conhecia, nunca tinha vivido, em uma problemática agrária de produção de algodão que eu tampouco sabia como se semeava, nem mesmo como era uma planta de algodão. Foi um aprendizado muito importante, foram três anos importantes de minha vida convivendo nesse contexto, muito marcado por uma prática em que a reflexão e a ação se juntavam. 
Ademais, isso também acontece em um momento em que eu estava estudando filosofia. Por um lado, eu estudava filosofia, e, por outro, desenvolvia essa prática organizativa e de alfabetização. É uma coisa muito interessante, digamos, que eu tenha tido essa oportunidade. E daí já todo um processo de vínculos com outros movimentos organizativos e a raiz da compreensão da educação popular como processo que creio ser algo que atravessa o que vai acontecer depois: fui me vinculando a processos em nível nacional no Peru, depois participei de processos de contato com pessoas de outros países. Vim para a América Central na época da luta contra a ditadura de Somoza. Tomei contato com gente da Frente Sandinista, me integrei ao comitê peruano em solidariedade à Nicarágua e, quando ganhou a Frente Sandinista de Libertação Nacional, vim à Costa Rica com minha família para trabalhar com educação popular na Nicarágua, na pós-alfabetização e em muitos outros projetos de capacitação e formação popular. Aí, no encontro com outras companheiras e companheiros, nasceu a ideia de criar a rede Alforja como rede de educação popular de solidariedade e ação mesoamericana. Isso em 1980, 1981. Para coordenar a rede Alforja, é criado o Centro de Estudos e Publicações Alforja na Costa Rica, onde eu trabalho desde então.

No ano de 1983, há um encontro latino-americano na Nicarágua onde praticamente se cria o CEAAL (Conselho de Educação de Adultos da América Latina); momento em que chega Paulo Freire como seu presidente. Eu sou convidado à reunião do Comitê Diretivo do CEAAL nessa primeira reunião na qual se ia definir o estatuto desse importante projeto latino-americano de educação de adultos e, depois, de educação popular.

Uma tarde tivemos uma conversa com Paulo Freire e outros dois companheiros. Foi uma longa conversa sobre a relação entre consciência e organização, em que Freire nos dizia: "posso antes haver pensado que a consciência é um momento prévio à organização, mas depois acabei criticando esse ponto de vista, pois os processos de organização e de consciência vão juntos". Ele também nos falava da relação entre o objetivo e o subjetivo: "às vezes você está em uma estrada e uma calçada é a subjetividade e a objetividade do outro lado, esses dois elementos estão em permanente relação". Nessa conversa, ele também tocou na temática da relação entre organização e educação; perguntamos: um dirigente popular é um educador popular? A tarefa educativa é algo essencial a seu rol de direção? Então ele disse "claro, mas temos que levar em conta que os caminhos dos processos populares são poeirentos, e por isso o dirigente tem que caminhar junto com a gente; se o dirigente vai 
muito adiante, o pó de suas sandálias vai tapar a visão do caminho dos outros, mas, se vai atrás, o pó que levantam as sandálias do povo não vai permitir ao dirigente prosseguir, por isso que tem que trabalhar junto com o povo e é assim que se faz uma educação libertadora". São falas de pura memória, mais que me marcaram muito.

E então, nasceu o CEAAL. Nasceu um movimento latino-americano de educação popular. Logo houve um evento no Brasil, em Piracicaba, onde estavam João Francisco de Souza, Moema Viezzer, Luz Rigal, Francisco Vio Grossi... pessoas que faziam o trabalho de educação popular na América Latina e em outros países. Nesse período, 1984 e 1985, com a solidariedade com o Chile - com o golpe no Chile -, a solidariedade com a Nicarágua e a educação popular que surge dessa dinâmica latino-americana, pelo próprio contexto vivido, revela muitas coincidências para as pessoas que fazem educação popular. Esse é um tema para relacionar o aporte ou a característica particularmente presente na educação popular latinoamericana e que vem de toda essa unidade e diversidade dos processos os quais vivemos.

\section{O esforço de construir uma educação popular eminentemente latino-americana e a relação com o anticolonialismo}

Oscar Jara - Nesse tempo, o que fazíamos era pensar em elementos da identidade política organizativa, a aspiração de um processo de mudança e transformação social. Mas eu acho que não era tão presente essa ideia de que temos um conhecimento colonizado e que há, digamos, uma raiz de identidade que tem um saber que é necessário recuperar - outra epistemologia - e romper, portanto, com essa relação colonial. Mas há um ponto de confluência, que são esses fatores de identidade que nos unificam como América Latina. Esse, talvez, naquele momento, foi o fator mais percebido como elemento sociopolítico que marcou nossos processos e nossas aspirações de mudança. Agora, dentro disso, há um elemento que é muito importante e que tem relação com o serviço social e com o método de sistematização de experiências. As pessoas que estavam no serviço social viveram algo parecido ao que aconteceu conosco, os educadores populares, que estávamos, nesse momento, apostando na transformação social, escutando as problemáticas das pessoas e refletindo a partir disso: nos anos 60, o serviço social e sua organização latino-americana de ensino e pesquisa, a ALAEITS, passa a questionar e rever o foco do seu trabalho - que era dirigido na linha da OEA e tinha um marco de referência trazido do norte, Estados Unidos e Europa, com atuação 
a partir dos estudos de caso, grupo e comunidade, enxergando as pessoas com problemas tidos como disfuncionais ou não ao sistema e, por isso, tinham que recuperá-las. Por isso, ao início chamaram de "assistência social", que mudou para "serviço social"; chegou, então, um momento que se chamou de "reconceitualização do serviço social como trabalho social". Ou seja, a partir da realidade da América Latina, foi-se criando outros marcos de concepção, um pensamento próprio que surge de nossa realidade. E eu acredito que o produto da ruptura epistemológica, causada pela Revolução Cubana, demonstra que, a partir da América Latina, podemos pensar uma sociedade sem utilizar marcos de referências conceituais europeus e norte-americanos, mas nossos próprios marcos. Isso se aplica ao processo educativo e à atuação do serviço social.

Nesse sentido, há um encontro de trabalho social em 1971, no Equador, em Ambato, onde Leila Lima, da Universidade de Belo Horizonte, faz a apresentação de um trabalho em que relaciona a prática como fonte de produção de teoria, e é o que eu até esse momento identifiquei como a origem, o primeiro documento a trazer o termo sistematização de experiências com o sentido que usamos agora. Ela dizia: o serviço social reconceitualizado mostra que há uma prática e que, a partir dela, é possível construir um conhecimento sistemático para produzir a teoria - o serviço social como área do conhecimento específica, apartada da sociologia, economia, antropologia que estavam surgindo nesse momento na América Latina. Ela dizia “nós, assistentes sociais temos uma vivência prática dos problemas sociais, e, portanto, há um conhecimento que tem que ser valorizado e essa prática necessita que se faça e se produza um conhecimento sistemático; portanto temos que sistematizar as experiências do serviço social". Surge, então, no serviço social, a palavra sistematização, que logo vai fazendo parte de um patrimônio comum para a educação popular e outros processos semelhantes, incluindo teatro do oprimido, pesquisa ação, pesquisa participativa, ou seja, processos de produção de conhecimento a partir das práticas. Esse é meu contato documental posterior em uma busca de onde apareceu pela primeira vez a palavra sistematização e que a gente usa agora sempre com o sobrenome: sistematização de experiências. Esse é o ponto de contato que eu, nos anos 90, descubro como uma referência inicial. 


\section{A educação popular e o Serviço Social no Brasil}

Houve uma aproximação da profissão à educação popular em seu projeto de "intenção de ruptura", com o método de BH. Todavia, nas décadas de 1980 e 1990, ocorreu um distanciamento, expresso pela baixa produção acadêmica, inclusive com contundente crítica de José Paulo Netto, a partir do livro Ditadura e serviço social: uma análise do serviço social no Brasil pós-64, referência teórica na profissão.

Oscar Jara - Sobre isso que você me diz penso que possam haver três coisas importantes, a primeira é durante os anos 80 a experiência do processo chileno, logo da repressão, logo das ditaduras de Argentina, Uruguai, onde as experiências influenciadas por Paulo Freire de educação libertadora vão se espalhar pelo resto de América Latina. Nessa época, Carlos Rodrigues Brandão e sua equipe vão trabalhando em vários países, divulgando o método de Paulo Freire que começa a ter um conhecimento e um impacto no resto da América Latina. A experiência chilena de Freire, seu livro Pedagogia do oprimido e seu método de alfabetização são elementos que passam por toda a América Latina. Tenho encontrado textos dos anos 72 , 73, na Venezuela, na Colômbia, aqui mesmo na América Central circulavam textos que influenciavam e traziam esse pensamento vivo de Paulo Freire. Também outro fator foi o exílio de outros educadores e educadoras populares, porque muita gente chilena e argentina, uruguaia em menor número, os brasileiros, precisamente pelo impacto das ditaduras que vêm aos outros países e trazem essa abordagem. Por exemplo, eu conheço João Bosco Pinto que chega no Peru, que trabalha com pesquisa-ação participativa também e sobre o tema da alfabetização, isso nos anos 73 a 75, então há aí uma extensão de "produtos" do exílio, isso como a outra cara do exílio em que se difunde a educação popular na América Latina.

Outra coisa também é a aparição do nome “educação popular”, porque até o ano 71, 72, Paulo Freire não fala e não tem textos usando o nome educação popular, isso até quase o ano 2000. Ele escreve sobre isso, mas não tematiza que se chame educação popular a sua proposta de uma educação libertadora. É Carlos Brandão e sua equipe que vão desenvolvendo essa reflexão e, ao juntarem a ideia de uma educação libertadora como parte de um movimento popular e relacionada com o movimento de cultura popular no Brasil, o movimento de educação libertadora se mescla a isso e aparece o termo "educação popular". Esse termo, então, começa a difundir-se no ano 1970 em um livro de Júlio Barreiro, que na verdade é 
Carlos Brandão o autor, que como está no Brasil prefere não usar seu nome, que se chama Educação Popular e Processo de Conscientização. Esse livro também se difunde muitíssimo e é como uma contrapartida aos textos freireanos e começa a haver toda uma reflexão e a criação de centros de educação popular, onde nos constituímos. No ano 72, já éramos alfabetizadores que fazíamos educação popular. Não tenho certeza, mas penso que algumas assistentes sociais faziam educação popular, mas a partir do serviço social, assim como educadores faziam educação popular desde a pedagogia. Começa a se mesclar esse tipo de função e a educação popular acaba sendo um elemento mais geral, que passa a ser referência de uma maneira de fazer outro tipo de educação, mais horizontal, dialógica e crítica, e isso tinha muito a ver com a questão da conscientização e organização popular.

Outro fator é a revolução sandinista. Na revolução sandinista tem experiências de educação popular que surgiram em alguns grupos cristãos na Nicarágua, vinculados também à teologia da libertação, que, na luta contra Somoza, nesse processo de solidariedade, haviam estado muito presentes. No momento em que triunfa a revolução sandinista, parece que a educação que se deveria fazer desde o Estado era a educação popular, e isso pela primeira vez, porque propriamente no governo de Allende no Chile não se fala tão explicitamente que a proposta do governo de Allende, de união popular, era uma proposta de educação popular. Na Nicarágua revolucionária isto se explicita. Aí se rompe a ideia dos anos 60 a 80 de que a educação popular é uma educação marginal, não formal, alternativa. A oposição tradicional sempre foi “educação formal versus educação popular". Se pensava assim: educação formal é uma educação burguesa, tradicional, vertical, autoritária e a educação popular é democrática, participativa, dialógica, revolucionária. Quando um governo revolucionário diz que toda a educação deve ser educação popular e pretende que todo o sistema educativo deve orientar-se pela educação popular, já se está firmando que educação popular é outra concepção de educação que atravessa todas as modalidades e não apenas uma específica. Não é educação de adultos somente, não só alfabetização somente, não é educação não formal. É outra concepção total de educação. Então nos anos 80 começa uma reflexão de outro nível sobre a concepção de educação popular. 
O conceito de educação popular e a relativa polissemia de referenciais teóricos e perspectivas políticas

Uma das críticas à educação popular feita pelo Serviço Social brasileiro é a de Durigueto (2012, p. 200) que afirma ser "preciso amadurecer melhor, no debate profissional, a compreensão do conteúdo teórico que perpassa as reflexões situadas sob a denominação de educação popular. Embora remeta, de modo geral, à mobilização, conscientização e organização das classes subalternas, seus agentes pautam-se em referências teóricas e políticas diversas, o que resulta em projetos que não necessariamente convergem para o mesmo horizonte sociopolítico". Nessa linha, há também a questão sobre as organizações vinculadas ou não às universidades que atualmente desenvolvem, praticam e se autointitulam "educação popular", muitas vezes com perspectivas muito diferentes.

Oscar Jara - Esse tema atravessa a história da construção política da educação popular na América Latina. Vamos retroceder um pouco, nos anos 30, quando se formam, um pouco antes das universidades populares, os movimentos sindicais, o movimento anarco-sindicalista, partidos socialistas... todos esses movimentos estavam acompanhados de algum tipo de trabalho cultural ou educativo: formam bibliotecas populares, criam cursos e a própria ideia do Manifesto da Universidade de Córdoba de 1918, o movimento de criação da extensão universitária como forma de trabalho em que a universidade tem que vincular-se ao povo. Mas aparece a ideia de que a universidade é um núcleo fechado do saber que tem que levá-lo para as pessoas que não o têm. Então há uma visão um pouco paternalista, nesse sentido; mas ela não é absoluta, pois há outras pessoas, como José Carlos Mariátegui, que no ano 1928, no Perú, chega à universidade Popular Gonzáles Prada, ao mesmo tempo em que levava a cabo um trabalho com os operários de Lima. Ele vem da Europa (Itália), influenciado pelo contexto do nascimento de partidos socialistas e pela crise que começa a viver a Europa depois da primeira guerra mundial e o surgimento do nazismo. Ele pleiteia, e está em seus textos, discutir a crise mundial, e ele diz claramente "eu não venho ensinar-lhes a crise mundial, eu venho estudá-la com vocês, vamos construir em conjunto, pois essa é a única cátedra de educação popular que existe no Peru, nesse diálogo entre a realidade peruana e a realidade mundial". Nos anos 30, está tendo um confronto entre os partidos comunistas tradicionais que, no congresso latino-americano dos partidos comunistas em Montevidéu, tomam a decisão de não se chamarem partidos socialistas, mas comunistas, a filiar-se à Terceira 
Internacional e tratar de assumir a concepção mais ortodoxa do materialismo histórico e da perspectiva comunista como a teoria sobre a qual tem-se que se construir a nova sociedade. Desde essa época, em muitos partidos, sobretudo os partidos comunistas, criam currículos com conteúdos para poder ensinar a teoria, ou seja, transmitir às pessoas a teoria marxista e a teoria leninista. Isso atravessa muitos movimentos, não todos, nos anos 40 e 50. Assim, sempre há uma teoria revolucionária que acompanha o processo de organização. Inclusive com base em Lênin, que diz que sem teoria revolucionária não há prática revolucionária. Essa teoria definida, digamos, pela Terceira Internacional dirigida pelo partido comunista da União Soviética é tomado por todos os partidos comunistas sul-americanos como marco de interpretação teórico a ser aplicado. Mariátegui, pelo contrário, defende a ideia de que temos que repensar o que é o socialismo a partir da realidade latino-americana e que esse socialismo não pode ser cópia do que acontece na Europa, mas uma criação heroica. Ele fala de um socialismo indo-americano. Então, eu diria que desde esse momento haverá essas duas correntes: a que defende a existência de uma teoria a ser transmitida para as pessoas e, assim, gerar um movimento revolucionário; e a outra que aposta na necessidade de construir a partir da própria realidade a teoria que requeremos para nossa própria situação. Eu creio que Freire está nessa segunda corrente, ou seja, o desenvolvimento de uma teoria libertadora, seu próprio método de alfabetização, a ideia de um processo dialógico e a relação educador-educando na forma horizontal, rompe com essa ideia de que existe uma verdade preestabelecida que tenha que ser transmitida.

No Chile, nos anos 70, na economia popular aparecem essas duas correntes muito definidas. O grupo freireano, que trabalha com o processo da reforma agrária no Chile. Nesse período se produz também os Cadernos de Educação Popular, de Marta Harnecker e Gabriela Uribe. Também Marta escreve "conceitos fundamentais do materialismo histórico", que é um livro de análises sobre o marxismo, o materialismo histórico e seus principais conceitos teóricos de referência, que se tiram uns dez caderninhos sobre aspectos particulares dessa concepção, exemplo "explorados e exploradores", "a luta de classes", “o partido e a organização", ou seja, são dez cadernos ilustrados de divulgação popular, em que o primeiro desses livros diz que o movimento operário e o movimento popular precisam de uma teoria revolucionária, mas nesses materiais de educação popular contém a teoria revolucionária que necessita o movimento operário para fazer a revolução. 
Eu diria que são duas correntes que acompanham até agora os processos de educação política na América Latina, sempre com a discussão: se a teoria está preestabelecida e tem que ser transmitida ou tem-se que construir capacidade de reflexão teórica e a construção de uma teoria desde a própria realidade. Nessa discussão que você me diz que ocorre, eu vejo assim, ao se ir difundindo uma ideia de educação popular e processos de organização na América Latina começam a surgir novos movimentos de organização; ou seja, agora não é somente a classe operária e os sindicatos, aparecem as lutas camponesas, depois aparecem as lutas dos movimentos de direitos humanos, depois aparece a luta das mulheres, aparecem a luta do movimento negro e dos movimentos indígenas; começa a haver uma diversificação dos movimentos. Então, eu entenderia, sobre o que disse Maria Lúcia Duriguetto, que efetivamente há uma polissemia, mas uma polissemia produto de distintas matrizes culturais e organizativas, as quais isso que se chama educação popular efetivamente aparece como um parâmetro, um guarda-chuva de referência que pode ir desde os dois extremos, o que seria uma conscientização mais assistencialista - eu faço educação popular para atender aos pobres que necessitam uma ajuda para melhorar sua vida -, até uma construção muito mais radical de dizer que temos uma teoria revolucionária e as pessoas têm que aprendê-la para poder buscar processos revolucionários. Tudo isso entra no que chamo de práticas de educação popular.

Nos anos 80, especificamente em 1984, tem uma discussão, inclusive tenho um pequeno texto que escrevi, que tem um capítulo que se chama "Educação popular, um conceito em busca de definição", e que já desde esse momento aponta que existem distintas formas de entender o que passa no que chamamos de educação popular e se tem que fazer um debate em função de seu significado concreto para esses processos. Até porque não é o mesmo ter um processo de educação popular na Nicarágua sandinista e fazer nesse momento nas zonas de controle militar na Guatemala, ou o que poderia significar fazer no Chile de Pinochet. Todos falávamos em "educação popular", mas a maneira de como se fazia ou o que significava podia ser muito diferente, dependendo do contexto. Aqui é um ponto, em que já é minha interpretação, e eu creio que não é possível falar "da" educação popular como se fosse tudo homogêneo e falar dos educadores populares como se fôssemos todos iguais; mas falarmos de processos de educação popular; processos que têm algumas características: desenvolvimento da capacidade formadora das pessoas, que são coletivos, que desenvolvem o pensamento crítico, que partem da realidade concreta, que vinculam a prática com a teoria; e, portanto, 
dependendo do contexto econômico, social, político e também cultural, se chama e se nomeia de diferentes maneiras.

Todavia, a educação popular, no sentido político, tem uma intenção transformadora. Então, surge uma reflexão, que não sei se ajuda para esse debate: se você olha a educação popular como algo que deveria ser homogêneo, a polissemia é negativa; e esta é uma forma de encarar. Para mim, parece que a polissemia é natural em processos que podem ser muito diferentes, de acordo com o contexto, o momento etc. Mas onde estão os elementos básicos que identificariam o que é uma educação popular? Aqui podemos ter referências: uma primeira concebendo o popular em um sentido amplo da palavra, como referência de povo, e povo se relaciona com processos democráticos para construir a democracia - direitos de todas as pessoas sem distinção. Mas temos um segundo sentido, mais específico, o popular referido a todos aqueles setores que sofrem algum nível de assimetria ou de subordinação, ou seja, por exploração econômica, por dominação política, por discriminação de gênero, raça, marginalização, exclusão; qualquer desses processos gera um setor subalterno e subordinado. Esses setores são setores populares porque são dominados por uma política antipopular. Então, uma educação popular que tem como prioridade a aspiração dos direitos democráticos a todo o povo, nesse caso, tem como protagonistas esses setores sociais populares - a partir dos setores populares e com os setores populares. Em uma terceira concepção, temos o popular com sentido político, de um projeto político de transformação revolucionária da sociedade, e que, portanto, busca eliminar as razões da exclusão. Aí é onde entra a ideia da pedagogia do oprimido no sentido de superar exploração, a dominação, a discriminação, a marginalização. Essa é uma educação popular que aponta um processo histórico de transformação e libertação.

Então, visto dessa maneira, eu poderia dizer que há uma polissemia na educação popular de base conceitual e de prática decorrente do contexto; mas que todos fazem educação popular, pois trabalham em função de processos organizativos, políticos, pedagógicos e éticos que buscam eliminar essas relações de desigualdade. A partir dessa colocação eu poderia direcionar para a discussão no serviço social; ou seja, como se colocam as escolas de serviço social e como se colocam os e as profissionais do serviço social nesse marco. No processo de discussão que houve nos anos 80, eu creio que na América Latina, enfatizou-se a ideia desse terceiro elemento, a educação popular no sentido político; mas existia muita gente que podia 
entendê-la em outro sentido. Então, para os e as profissionais do serviço social há questionamento de que tipo de educação popular está realizando: uma tendência mais assistencial, mais socialmente vinculada com os setores com os quais atua ou uma tendência mais político-ideológica com perspectiva revolucionária?

\section{A educação popular e serviço social: princípios que atravessam a atuação profissional}

Oscar Jara - Existe uma fundamentação ético-político-pedagógica que marca um processo de educação popular, não falando da educação popular, mas dos processos de educação popular. Um aporte importante do Brasil foi precisamente colocar os processos de educação popular vinculados às políticas públicas, especialmente a política social, depois, em geral, a todas as políticas públicas. A mim também coube estar no Brasil nos anos de 2012 e 2013, antes do golpe, em que a secretaria geral da presidência me convocou para coordenar um evento latino-americano com o objetivo de discutir um marco de referência de educação popular para trabalhar com as políticas de participação social, como componente central da política pública; ou seja, toda política pública deveria ser participativa, precisamente na linha da democratização. Mas para democratizar, para que haja uma política pública participativa, tem que haver um processo de educação popular, ou seja, educação popular como componente de uma política pública participativa. Esse foi um decreto anulado na câmara dos deputados e que eu tenho todos os materiais, essa é uma proposta para mim possível de ser pensada por qualquer governo.

Há um sustento na fundamentação ético-política-pedagógica dos processos de educação popular que atravessa o tema das políticas públicas, mas também o trabalho de qualquer pessoa que faça um tipo de trabalho social, não só quem é assistente social; ou seja, alguém que trabalhe em um hospital, ou uma pessoa que dá aulas em uma escola, qualquer pessoa que faça trabalho com setores sociais e populares, eu creio que há uma dimensão da educação popular que deveria estar presente em suas práticas, de acordo com esse processo éticopolítico-pedagógico. Eu juntaria como três dimensões articuladas, porque o ético-político não seria apenas como intenção, que essa intenção tem que ser coerente com a ação que implica. Então, resumindo, se eu sou assistente social, que trabalho com o povo (a gente), qual é a base ético-político-pedagógica e metodológica com que trabalho? É impositiva, autoritária, vertical, domesticadora, eu tenho a verdade e assim a passo. Ou onde estou trabalhando estou 
gerando protagonismo, autonomia, fortalecendo a capacidade do próprio povo? Eu sou um médico, um enfermeiro, eu aplico a medicação e me vou ou trato a pessoa de forma que ela compreenda sua situação de saúde, a lógica do autocuidado, compreenda seu corpo, compreenda a situação. Todavia, cada caso vai ser um caso. Eu posso ter meu aporte de conhecimentos médicos, mas a pessoa que estou atendendo tem sua vivência. Então, eu não posso simplesmente dizer você tem isso e aquilo, tome essa medicação. Eu tenho que compreender e escutar o que ele diz, como se sente e de que maneira o que eu sei se relaciona com o próprio saber desse sujeito. Em qualquer campo que tenha presença social há sempre uma relação possível de diálogo de saberes. Você pode dizer eu sou policial, eu sou a autoridade, eu sou a lei e te impeço de fazer alguma coisa e te reprimo ou eu posso pensar que existe uma dimensão educativa e tem uma situação da qual posso partir para que você compreenda o sentido da lei. A questão é que você pode trabalhar com determinada situação, mas não impô-la.

Todo saber tem também uma parte de ignorância, todas as pessoas têm conhecimentos existentes e eu tenho que me direcionar neles, não posso impor a minha visão. Nesse sentido, o diálogo tem o propósito de gerar uma relação democrática, que permita respeitar as condições e características para que as pessoas sejam sujeitos, protagonistas autônomas e conscientes. Isso é um processo que vai gerando resultados, em que descubro que tenho capacidades, responsabilidades... e isso é político. No momento em que desenvolvo minha capacidade de análise, porque eu me coloquei para pensar outra coisa que não o que pensava antes, estou me formando como pessoa, como cidadão, como sujeito capaz de fazer trocas. Pode parecer ser uma coisa muito pequena, que ideologicamente não tenha nenhum discurso, mas isso pode ser muito importante para uma perspectiva da educação popular. Quase que obrigatoriamente um assistente social precisa se colocar diante deste dilema: como fazer, qual é a sustentação ético-política-pedagógica, qual é seu ponto de partida, o que você vai aprender com as pessoas com as quais vai trabalhar? É aí onde veria que os princípios de educação popular atravessam a atuação profissional. Mas que, até não se chama assim, pode ser que seja nomeado de outra maneira, mas está presente. 


\section{A educação popular e desafio no processo de organização social e conscientização política}

Oscar Jara - A ideia de processo misturado com a ideia de arte deve nos levar a gerar questionamentos críticos. Creio que pode haver momentos nos quais o processo dialógico, que sempre tem que ser respeitoso, possa ser levado de tal maneira que, ao final, as duas pessoas que estão em diálogo podem passar a outro nível de questionamento a partir do que estamos pleiteando. Pode ser que isso ocorra de maneira muito suave em algum momento, mas também por meio de uma confrontação. Ou seja, eu estou com um grupo e tenho uma responsabilidade de coordenação, temos duas horas para trabalhar algo. Eu tenho que partir do que as pessoas sabem, conhecem, querem, sentem e tenho que ter uma proposta metodológica de como partir para que todos estejamos localizados no que vamos fazer. Agora, eu não sou neutro nem invisível e então eu tenho uma opinião também se sou parte desse grupo que estamos construindo. Que eu possa e consiga converter algo que foi dito em uma pergunta “por que isso seria assim?", ou "aonde nos vai levar isso?". Por isso eu sempre ponho crítica à palavra facilitador, tem um ditado popular, o educador popular não é um facilitador, é um desafiador ou uma desafiadora, é um problematizador ou uma problematizadora. Muitas vezes se pensa que quem está dando a palavra aos demais não tem palavra, não, nesse debate não que eu tenha a verdade ou tenha a resposta para poder dizer ao final "não, você está equivocado", nesse caso sim seria muito manipulador e autoritário. É igualmente manipulador se colocar como quem não sabe de nada. Nesse sentido, todo processo de educação popular em determinado momento deve nos permitir ser problematizadores e questionadores. Não é uma questão simples, mas muitas habilidades que vão se desenvolvendo, são desenvolvidas na prática, quando se defronta com outros tipos de grupos.

Nós temos trabalhado bastante o tema da formação metodológica e fazemos exercícios em que enfrentamos distintas situações e aparecem esses estereótipos, o educador que dá a palavra e não diz o que tem que dizer. Como faz para viver um processo em que você também se questiona? Para mim a noção clara é a noção freireana de desafio, eu vivo encontrando com essa inquietação várias coisas que Freire em algum momento faz referência em Pedagogia da Autonomia, para ser democrático. Ele vai gerando a inconformidade, o questionamento; o sujeito que não se satisfaz com a primeira resposta, são signos que te dizem "olha que interessante não está satisfeito com as minhas respostas", me obriga a pensar, me desafia para 
que eu o desafie. O ponto é viver para ser desafiado por coisas complicadas; e isso temos que aprender a viver. Por exemplo, quando você me traz essas perguntas aqui me provoca e me faz pensar. Isso às vezes cansa muito, pois, no fundo, temos a ideia de que o educador tem que saber de tudo e ter todas as respostas e não pode dizer que não sabe, que se põe a pensar junto "olha que interessante o que você está levantando aqui". A ideia de desafio é muito potente para uma relação crítica; mas para ser possível o educador ou educadora tem que ter disposição de aprendizagem. Se você não tem disposição de aprender, nunca vai se sentir desafiado, somente vai sentir que desafia. Se você tem a disposição de aprender não importa que a coisa mais complicada apareça: vamos ver, vamos investigar como convertemos nossas ignorâncias parciais com os saberes e ignorâncias das outras pessoas. Nesse sentido, eu penso que as(os) assistentes sociais têm oportunidades potentes de se meter no mundo com as coisas do mundo.

\section{Referências}

DURIGUETTO, M. L.; BALDI, L. A. P. Serviço social, mobilização e organização popular: uma sistematização do debate contemporâneo. Katálysis, Florianópolis, v. 15, n. 2, p. 193202, 2012. Doi: 10.1590/S1414-49802012000200005.

GADOTTI, M. Educação popular, educação social, educação comunitária: conceitos e práticas diversas, cimentadas por uma causa comum. Diálogos, Taguatinga, v. 18, n. 1, p. 1032, 2012. Disponível em: https://portalrevistas.ucb.br/index.php/RDL/article/view/3909/2386. Acesso em: 15 nov. 2019.

LEONARDI, F.; ASSUMPÇÃO, R. Educação popular na universidade: uma construção a partir das contradições, reflexões e vivências a partir do PET Educação Popular da UnifespBaixada Santista. e-Curriculum, v. 14, n. 2, p. 437-462, 2016. Disponível em: https://revistas.pucsp.br/curriculum/article/view/27448. Acesso em: 15 nov. 2019.

NETTO, J. P. Ditadura e serviço social: uma análise do serviço social no Brasil pós-64. São Paulo: Cortez, 1991.

Submetido em 9 de março de 2020.

Aprovado em 20 de abril de 2020. 